\title{
Distribution of Putative D4 Dopamine Receptors in Postmortem Striatum from Patients with Schizophrenia
}

\author{
Angela M. Murray, ${ }^{1}$ Thomas M. Hyde, ${ }^{1}$ Michael B. Knable, ${ }^{1}$ Mary M. Herman, ${ }^{1}$ Llewellyn B. Bigelow, ${ }^{1}$ Joye M. \\ Carter, ${ }^{2}$ Daniel R. Weinberger, ${ }^{1}$ and Joel E. Kleinman ${ }^{1}$ \\ 'National Institute of Mental Health, Clinical Brain Disorders Branch, Intramural Research Program, St. Elizabeths \\ Hospital, Washington, D.C. 20032 and ${ }^{2}$ Office of the Chief Medical Examiner, Washington D.C. 20032
}

\begin{abstract}
The identification of five dopamine receptor subtypes has given the dopamine hypothesis of schizophrenia new life. The D4 receptor is particularly intriguing because it binds clozapine with high affinity. Putative D4 receptors were labeled in postmortem human brain by subtracting the binding of a saturating concentration of ${ }^{3} \mathrm{H}$-raclopride $(6 \mathrm{~nm}$, which labels D2 and D3 receptors) from that labeled by a saturating concentration of $\left[{ }^{3} \mathrm{H}\right] \mathrm{YM} 09151-2$ (1-1.3 nM, which labels D2, D3, and D4 receptors). In the control brain, putative D4 receptors show a homogenous distribution in striatum and nucleus accumbens. This is also true in schizophrenic brains, although the levels are significantly higher (twofold). These data are inconsistent with mRNA studies that have shown negliglble amounts in strlatum and accumbens, with modest amounts reported in most of cerebral cortex. These findings suggest that the putative D4 receptors are not synthesized in this region, but are presynaptically localized on striatal afferent terminals. Our findings confirm and extend the report of Seeman et al. (1993). Extension of these findings into the nucleus accumbens is important because of its extensive connections to the limbic system while the putamen is exclusively "motor" striatum.
\end{abstract}

[Key words: D4, dopamine receptors, schizophrenia, autoradiography, postmortem, brain]

The notion that excess dopaminergic activity leads to the psychotic symptoms of schizophrenia is based on pharmacological findings. Agonists can cause or exacerbate these symptoms (Connell, 1958; Griffith et al., 1972) while dopamine D2 receptor blockade correlates with antipsychotic efficacy across a wide range of ncurolcptics (Creese et al., 1976; Seeman et al., 1976). Direct evidence to support the dopamine hypothesis from postmortem schizophrenic brains (for review, see, Kleinman and $\mathrm{Na}$ wroz, 1994) and in vivo neuroimaging studies has been inconclusive (Wong et al., 1986; Farde et al., 1987; Martinot et al., 1990; Hietala et al., 1994).

DA receptors were originally divided into two major types, D1 and D2, based on pharmacological and biochemical criteria. As a result of recent advances in molecular biology, five distinct neuronal DA receptor genes have been identified (D1-D5; Gran-

\footnotetext{
Received Junc 21, 1994; revised Aug. 22, 1994; accepted Sept. 15, 1994.

We acknowledge the excellent technical assistance of Christopher F. Spurney.

Correspondence should be addressed to Angela M. Murray, Ph.D. at the above address.

Copyright (C) 1995 Society for Neuroscience $0270-6474 / 95 / 152186-06 \$ 05.00 / 0$
}

dy et al., 1989; Sokoloff et al., 1990; Sunahara et al., 1990, 1991; Van Tol et al., 1991). Genes encoding receptors belonging to the "D1-like" family include D1 and D5 receptors, while the "D2-like" family includes D2, D3, and D4 receptors. The receptors are distinguished on the basis of their molecular structure, mRNA coding and anatomical distribution, chromosomal location, and biochemical and pharmacological profile (Sibley and Monsma, 1992, for review). The discovery of three new dopamine receptors has given the dopamine hypothesis new life.

Typical neuroleptics are both D2 and D3 blockers, although the pharmacological profile for the atypical neuroleptic clozapine suggests that D2 or D3 receptor antagonism is not the locus of its mechanism of action (Sokoloff et al., 1990). Clozapine has a 10-fold higher affinity for D4 than that for D2 sites (Van Tol et al., 1991). The neuroanatomical locus for antipsychotic efficacy appears to be in the striatum/nucleus accumbens for both D2 receptors (Seeman, 1992) and D4 receptors (Seeman et al., 1993a). There appears, however, to be a mismatch for mRNA localization for D4 receptors insofar as there are relatively negligible concentration of D4 mRNA in the striatum/nucleus accumbens (Meador-Woodruff et al., 1994a,b).

In a recent study, Seeman (1993a) identified putative D4 receptors by subtracting the binding of ${ }^{3} \mathrm{H}$-raclopride $+\mathrm{Gpp}(\mathrm{NH}) \mathrm{p}$ (which labels D2 and D3 receptors) from that of ${ }^{3} \mathrm{H}-\mathrm{YM} 09151$ 2 , which, from pharmacological studies has been shown to label D2, D3, and D4 receptors (Seeman et al., 1993b). Using homogenate binding on postmortem human putamen, Seeman et al. reported a two- to sixfold increase in D4 binding in a schizophrenic population compared to the control group (Seeman et al., 1993a,b).

The following study employed quantitative receptor autoradiography (1) to visualize putative $\mathrm{D} 4$ receptors in human striatum, (2) to determine the anatomical distribution of putative D4 receptors in human striatum, and (3) to compare the amount and distribution in our schizophrenic population to a number of control groups and to test the hypothesis that elevation in "D2-like" receptors in schizophrenia was a consequence of previous exposure to neuroleptics. Putative D4 receptor numbers were compared between schizophrenics and three control populations: neurological controls, neuroleptic controls, and nonschizophrenic suicides. This study tests the notion of the specificity of the findings with respect to psychiatric diagnosis and neuroanatomy.

\section{Materlals and Methods}

Materials. ${ }^{3} \mathrm{H}-\mathrm{YM}$ 09151-2 (81.4 Ci/mmol) and ${ }^{3} \mathrm{H}$-raclopride $(79.5 \mathrm{Ci} /$ mmol) were purchased from New England Nuclear (Boston, MA). $(+)$ Butaclamol was purchased from Research Biochemicals Internation- 
Table 1. Patient demographics

\begin{tabular}{lllll} 
Diagnosis & $N$ & Age (range) \pm SEM & Sex & PMI \pm SEM \\
\hline Schizophrenia & 7 & $59.14(34-80) \pm 6.1$ & $4 \mathrm{~F} / 3 \mathrm{M}$ & $19.36 \pm 3.8$ \\
Control & 7 & $55.71(33-87) \pm 6.7$ & $3 \mathrm{~F} / 4 \mathrm{M}$ & $28.04 \pm 5.3$ \\
Neuroleptic control & 8 & $51.75(28-81) \pm 7.2$ & $1 \mathrm{~F} / 7 \mathrm{M}$ & $33.1 \pm 7.12$ \\
Suicide & 7 & $50.57(23-86) \pm 8.5$ & $1 \mathrm{~F} / 6 \mathrm{M}$ & $18.3 \pm 2.9$ \\
\hline
\end{tabular}

al (Natick, MA). Gpp(NH)p and all other biochemicals were purchased from Sigma Chemical Co. (St. Louis, MO).

Preparation of brain tissue quantitative receptor autoradiography. Brain specimens in the NIMH brain collection were obtained from the Washington, DC, Medical Examiner's Office. Blood and urine samples were collected for toxicological analysis and for neuroleptic level determination. None of the subjects had measurable serum levels at the time of death. Psychiatric diagnosis was determined by independent review of medical records by at least two psychiatrists. Table 1 lists demographic information on all subjects included in this study.

As listed above, three different control groups were compared to the schizophrenic patient group. The first was normal controls. The second was a neuroleptic control group, described in Table 2, consisting of a mixture of diagnostic categories, united only in their previous exposure to neuroleptics. This group was included to ascertain if receptor changes in the schizophrenic population resulted from previous exposure to neuroleptics.

The third control group consisted of nonschizophrenic suicides, included for comparison, since many schizophrenics commit suicide.

After collection from autopsy, the brain tissue was dissected into 1 $\mathrm{cm}$ coronal slabs that were individually frozen in isopentane cooled on dry ice $\left(-40^{\circ} \mathrm{C}\right)$. Tissue blocks were stored at $-70^{\circ} \mathrm{C}$ until processed. Coronal sections $(14 \mu \mathrm{m})$ were cut from tissue blocks at $-20^{\circ} \mathrm{C}$ using a cryostat (Jung Frigocut 2800 , Nussloch, Germany) and subsequently heat mounted onto gelatin-coated slides. Slide-mounted sections were stored with desiccant inside plastic containers at $-70^{\circ} \mathrm{C}$ until used in assays.

3-H-YM 09151-2 assay (D2, D3, and D4 receptors). Slide-mounted sections were preincubated in buffer $(50 \mathrm{~mm}$ Tris-IICl, pII 7.4 at room temperature, $1 \mathrm{~mm}$ EDTA, $5 \mathrm{~mm} \mathrm{KCl}, 1.5 \mathrm{~mm} \mathrm{CaCl}{ }^{2}, 4 \mathrm{~mm} \mathrm{MgCl}_{2}$, $120 \mathrm{~mm} \mathrm{NaCl}$ ) for $10 \mathrm{~min}$. Sections were transferred to buffer containing a saturating concentration (1-1.3 nM) of ${ }^{3} \mathrm{H}-\mathrm{YM} 09151-2$ for 180 min. Nonspecific binding was determined in the presence of $10 \mu \mathrm{M}$ (+)butaclamol. The reaction was terminated by two 5 min rinses in icecold buffer followed by a dip in ice-cold double distilled water. Sections were dried under a stream of cold air and stored in desiccant overnight at room temperature before being placed in cassettes. Sections and tritiated microscales (Amersham Corp., Arlington Heights, IL) were apposed against ${ }^{3} \mathrm{H}$-ultrafilm (LKB Instruments, Gaithersburg, MD) for 6 $\mathrm{d}$ at $4^{\circ} \mathrm{C}$. Assay was carried out twice on adjacent sections and the results averaged.

${ }^{3} \mathrm{H}$-Raclopride assay (D2 and D3 receptors). Slide-mounted sections were preincubated for $1 \mathrm{hr}$ at room temperature in buffer containing

\begin{tabular}{|c|c|}
\hline Case & Diagnosis \\
\hline 1 & Bipolar disorder \\
\hline 2 & Bipolar disorder, alcohol abuse \\
\hline 3 & Major depressive disorder \\
\hline 4 & $\begin{array}{l}\text { Acute encephalopathy, systemic lupus erythematosus, } \\
\text { subacute bacterial endocarditis, right middle cerebral } \\
\text { artery infarction }\end{array}$ \\
\hline 5 & $\begin{array}{l}\text { Antisocial personality disorder, phencyclidine and } \\
\text { amphetamine abuse }\end{array}$ \\
\hline 6 & Psychotic disorder, not otherwise specified \\
\hline 7 & Dementia associated with alcoholism \\
\hline 8 & Dementia associated with alcoholism \\
\hline
\end{tabular}

$200 \mu \mathrm{Mpp}(\mathrm{NH}) \mathrm{p}$ to remove endogenous dopamine that is known to compete with ${ }^{3} \mathrm{H}$-raclopride for binding to receptors (Seeman et al., 1989). Sections were transferred to buffer containing a saturating concentration $(6 \mathrm{nM})$ of ${ }^{3} \mathrm{H}$-raclopride for $120 \mathrm{~min}$. Nonspecific binding was determined as before, in the presence of $10 \mu \mathrm{M}(+)$ butaclamol. The reaction was terminated and slide-mounted sections were dried as before. Sections were apposed against ${ }^{3} \mathrm{H}$-ultrafilm for $12 \mathrm{~d}$.

Sections were analyzed using a Macintosh computer-assisted image analysis system (NIH image 1.52, public domain). Units are expressed in $\mathrm{fmol} / \mathrm{mg}$ protein. The striatum was divided into dorsal-caudate, ventral-caudate, nucleus accumbens, dorsal-putamen, and ventral-putamen for separate regional analysis. Specific binding was determined by subtracting nonspecific from total binding. For ${ }^{3} \mathrm{H}-\mathrm{YM}$ 09151-2, nonspecific binding represented $30 \%$ total binding at a saturating concentration. For ${ }^{3} \mathrm{I}$-raclopride, it represented $14 \%$. Specific ${ }^{3} \mathrm{H}$-raclopride binding represented approximately 50\% of specific ${ }^{3} \mathrm{H}-\mathrm{YM} 09151-2$ binding. D4 receptor number was determined by subtracting the specific binding of ${ }^{3} \mathrm{H}$-raclopride (which binds to $\mathrm{D} 2$ and $\mathrm{D} 3$ receptors) from the specific binding of ${ }^{3} \mathrm{H}-\mathrm{YM}$ 09151-2 (which labels D2, D3, and D4 receptors), according to the strategy originally proposed by Seeman et al. (1993a).

Statistical comparisons between groups were carried out using oneway ANOVA for each individual subregion followed by post hoc Fisher PLSD comparison.

\section{Results}

\section{Specific ${ }^{3}$ H-YM 09151-2 binding}

Table 3 displays binding of various radioligands across patient groups. Specific ${ }^{3} \mathrm{HYM}$ 09151-2 binding differed across the groups [5.75(29), $p=0.0037$ ANOVA], in the dorsal caudate. Schizophrenics had increased binding compared to all other groups, $p<0.05$, by Fisher PLSD. A similar increase in binding was observed in dorsal putamen $[6.115(29) p=0.0027$ ANOVA], $(p<0.05$, compared to control, neuroleptic control, and suicide, Fisher PLSD), ventral caudate [3.397(29) $p=0.0327$, $p<0.05$, compared to control, neuroleptic control, and suicide, Fisher PLSD], and ventral putamen [3.884(29) $p=0.0203$ ANOVA, $p<0.05$, compared to control, neuroleptic control, and suicide, Fisher PLSD]. No significant increases in binding were observed in the nucleus accumbens.

\section{Specific ${ }^{3} \mathrm{H}$-raclopride binding}

No significant differences in binding were observed between groups for any striatal region for ${ }^{3} \mathrm{H}$-raclopride binding. Table 3 shows specific binding values for ${ }^{3} \mathrm{H}$-raclopride in the various groups. Binding shows slight but nonsignificant elevations in the schizophrenic group and slight but nonsignificant reductions in the neuroleptic control group.

\section{Putative D4 binding}

Putative D4 receptors show a fairly homogenous distribution in control striatum. Highest values were seen in ventral caudate $(49.58 \pm 5.5 \mathrm{fmol} / \mathrm{mg}$ protein) and nucleus accumbens (46.34 $\pm 5.8 \mathrm{fmol} / \mathrm{mg}$ protein). Dorsal caudate revealed $44.98 \pm 4.9$ $\mathrm{fmol} / \mathrm{mg}$ protein, dorsal putamen $43.39 \pm 6.5 \mathrm{fmol} / \mathrm{mg}$ protein, and ventral putamen $(42.7 \pm 5.35 \mathrm{fmol} / \mathrm{mg}$ protein) putative $\mathrm{D} 4$ 
Table 3. Binding results of radioligands in the various groups

\begin{tabular}{|c|c|c|c|c|c|}
\hline & Dorsal caudate & Ventral caudate & Nucleus accumbens & Dorsal putamen & Ventral putamen \\
\hline \multicolumn{6}{|l|}{${ }^{3} \mathrm{H}-\mathrm{YM}$ 09151-2 } \\
\hline Schizophrenic & $122.3 \pm 9.9 * \lambda$ & $105.8 \pm 6.4^{*} \psi \lambda$ & $110.2 \pm 15.7$ & $133.4 \pm 12.0^{* \mid \psi \lambda}$ & $124.0 \pm 7.2^{2 * \lambda \lambda}$ \\
\hline Control & $82.6 \pm 5.7$ & $79.8 \pm 6.7$ & $94.3 \pm 7.8$ & $87.8 \pm 5.6$ & $91.2 \pm 7.6$ \\
\hline Neuroleptic control & $88.3 \pm 9.5$ & $83.6 \pm 7.1$ & $90.9 \pm 7.3$ & $85.4 \pm 8.6$ & $92.2 \pm 8.9$ \\
\hline Suicide & $85.4 \pm 5.2$ & $81.9 \pm 5.4$ & $93.3 \pm 7.9$ & $94.2 \pm 8.7$ & $94.2 \pm 7.6$ \\
\hline $\mathrm{F} ; p$ & $5.75 ; 0.0037$ & $3.397 ; 0032$ & $0.723 ; 0.55$ & $6.12 ; 0.00275$ & $4.01 ; 0.0185$ \\
\hline \multicolumn{6}{|l|}{${ }^{3} \mathrm{H}$-Raclopride } \\
\hline Schizophrenic & $43.2 \pm 11.25$ & $33.84 \pm 7.3$ & $50.15 \pm 12.3$ & $47.14 \pm 15$ & $50.86 \pm 15.5$ \\
\hline Control & $34.5 \pm 7.9$ & $28.2 \pm 7.9$ & $47.2 \pm 7.7$ & $40.3 \pm 6.9$ & $45.29 \pm 7.5$ \\
\hline Neuroleptic control & $27.5 \pm 5.02$ & $27.8 \pm 4.9$ & $35.8 \pm 5.9$ & $29.04 \pm 6.2$ & $33.43 \pm 8.0$ \\
\hline Suicide & $42.2 \pm 3.9$ & $33.9 \pm 5.6$ & $46.5 \pm 4.3$ & $44.55 \pm 2.3$ & $46.9 \pm 1.9$ \\
\hline$F ; p$ & $0.939 ; 0.44$ & $0.274 ; 0.84$ & $0.592 ; 0.63$ & $0.8 ; 0.5$ & $0.621 ; 0.6$ \\
\hline \multicolumn{6}{|c|}{${ }^{3} \mathrm{H}-\mathrm{YM}$ 09151-2- ${ }^{3} \mathrm{H}-$ Raclopride } \\
\hline Schizophrenic & $79.1 \pm 10.9^{* *}$ & $71.9 \pm 7.4^{* 4}$ & $74.34 \pm 9.5^{* 4}$ & $86.3 \pm 13.7 * \psi \lambda$ & $73.2 \pm 11.9^{* 4}$ \\
\hline Control & $44.9 \pm 4.9$ & $49.6 \pm 5.5$ & $46.3 \pm 5.8$ & $43.4 \pm 6.5$ & $42.7 \pm 5.3$ \\
\hline Neuroleptic control & $60.3 \pm 6.42$ & $54.9 \pm 5.8$ & $60.2 \pm 4.2$ & $57.6 \pm 4.3$ & $59.0 \pm 4.12$ \\
\hline Suicide & $41.7 \pm 6.7$ & $46.0 \pm 6.8$ & $45.44 \pm 8.9$ & $56.2 \pm 6.5$ & $46.4 \pm 7.6$ \\
\hline$F ; p$ & $5.3 ; 0.0055$ & $3.13 ; 0.04$ & $3.38 ; 0.033$ & $4.64 ; 0.01$ & $3.16 ; 0.04$ \\
\hline
\end{tabular}

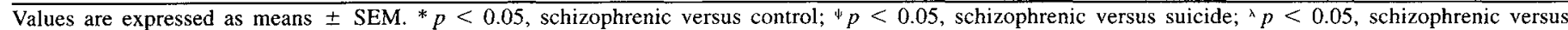
neuron. Units are expressed in $\mathrm{fmol} / \mathrm{mg}$ protein.

receptors. Figure 1 shows the distribution of D4 receptors in striatum and nucleus accumbens relative to $D 2$ and $D 3$ receptors.

Putative D4 binding in the various groups is displayed in Table 3 ( ${ }^{3} \mathrm{H}-\mathrm{YM}$ 09151-2 - ${ }^{3} \mathrm{H}$-raclopride). Putative D4 binding was significantly increased (in schizophrenics compared to controls, suicides, and neuroleptic controls, $p<0.05$, Fisher PLSD) in dorsal putamen [4.644(28) $p=0.013$, ANOVA]. Levels of putative D4 receptors were significantly higher in schizophrenics compared to normal controls and suicides but were not elevated compared to neuroleptic controls ( $p<0.05$, Fisher PLSD) in dorsal caudate [5.3(29) $p=0.0055]$, ventral caudate [3.13(29), $p=0.043$, nucleus accumbens [3.37(27), $p=0.035]$, and ventral putamen [3.17(29), $p=0.412]$. Figure 2 graphically represents this data.

\section{Discussion}

Using a radioligand subtraction method (Seeman et al., 1993a) putative D4 receptors are increased in schizophrenics relative to controls. This is in agreement with the previous findings of Seeman et al. (1993a), although it extends the findings demonstrating increases in putative D4 receptors in all regions of striatum and nucleus accumbens, where there is a homogenous distribution. Absolute values are lower than those in the Seeman study, possibly because the homogenate binding technique may reveal higher binding than slide-mounted sections. Extension of these findings into the nucleus accumbens is important because of its extensive connections to the limbic system while the putamen is exclusively "motor" striatum (Oades and Halliday, 1987; Alexander et al., 1990).

Significant controversy exists over the expression of D4 receptors in the brain. Previous studies using Northern blot analysis has shown levels of D4 mRNA in rat striatum and hippocampus to be present, but two orders of magnitude lower than levels of D2 mRNA (Van Tol ct al., 1991). A distribution profile by Northern blot was carried out in several monkey brain areas, indicating relatively high levels in frontal cortex, midbrain, medulla, and amygdala (Van Tol et al., 1991). Lower levels were detected in striatum and hippocampus with no signal in the cerebellum. This distribution is more consistent with a limbic rather than motor distribution. In a more detailed study using in situ hybridization histochemistry, modest amounts of D4 mRNA have been reported in the hypothalamus, amygdala, hippocampus, nucleus accumbens, and much of the cerebral cortex with relatively negligible amounts in the striatum (Meador-Woodruff et al., 1994a,b). Thus, there is a disproportionate number of putative D4 receptors in the striatum, far in excess of what the relative D4 mRNA levels would suggest. These findings imply that D4 receptors are not synthesized in the basal ganglia, but rather have a presynaptic localization on afferent terminals in the striatum. This issue is currently under further investigation in our laboratory. D4 receptors may exist on terminals of corticostriatal neurons and may allow for dopaminergic regulation of glutamatergic neurotransmission. Increases in putative D4 autoreceptors to compensate for increased glutamatergic activity in striatum is an interesting hypothesis to explain their elevation in schizophrenia.

A second major issue to be addressed with regard to these findings is whether or not neuroleptics are responsible for these results. As in Seeman's study, a neuroleptic control group was not found to be increased statistically relative to the normal subjects. Moreover, the toxicological screens in the schizophrenic group were negative, suggesting that they were drug free at the time of death. Although the duration of this drug-free period is unclear, it was sufficiently long that D2 and D3 receptors measured by ${ }^{3} \mathrm{H}$-raclopride binding were not increased relative to controls. This is in agreement with previous studies done in our group (Knable et al., 1994). None of these findings, however, definitely rule out a neuroleptic effect causing an increase in putative $\mathrm{D} 4$ receptors, but they certainly make it less likely.

Of the previous studies that observed increases in D2 receptors in schizophrenic basal ganglia, the radioligands used were those that have an affinity for D2, D3, and D4 receptors: ${ }^{3} \mathrm{H}-$ spiperone (Lee et al., 1978; Owen et al., 1978; Lee and Seeman, 1980; Mackay et al., 1982; Mita et al., 1986; Mjorndal and Win- 

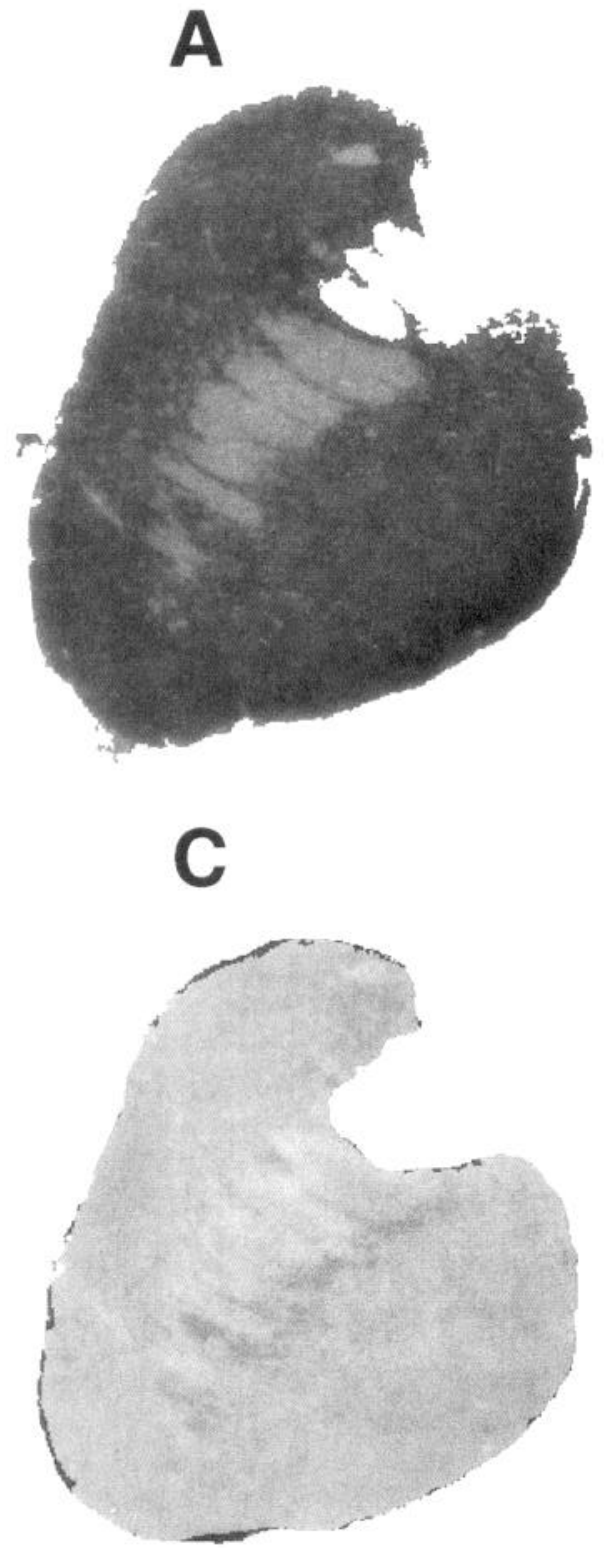
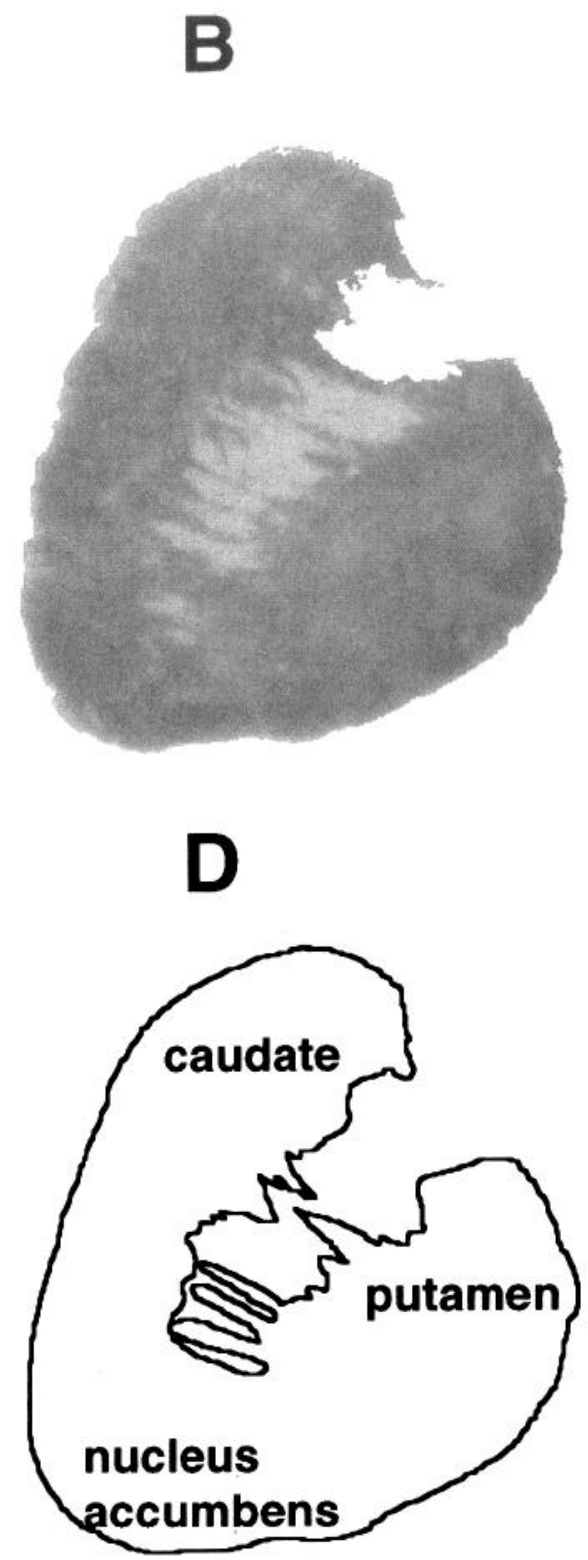

Figure 1. Photomicrographs from autoradiographs for binding of ${ }^{3} \mathrm{H}-\mathrm{YM} 09151-2$ to D2, D3, and D4 receptors, $\left(A\right.$, ${ }^{3} \mathrm{H}-$-raclopride to D2 and D3 receptors $(B) . C$ depicts putative D4 binding through computer-assisted subtraction of ${ }^{3} \mathrm{H}$-raclopride from ${ }^{3} \mathrm{H}-\mathrm{YM} 09151-2$. D shows a drawing delineating the structures from a control brain.

blad, 1986; Hess et al., 1987; Seeman et al., 1987), ${ }^{3} \mathrm{H}$-apomorphine (Lee et al., 1978; Lee and Seeman, 1980), and ${ }^{3} \mathrm{H}$-flupenthixol (Cross et al., 1981). Increases previously attributed to "D2" receptor density elevation may, instead, have actually reflected increases in D4 receptor density (Seeman, 1993a). Alternatively, these increases may have resulted from previous neuroleptic exposure (Mackay et al., 1982), Kornhuber at al., 1989). However, in studies where no change was detected, ${ }^{3} \mathrm{H}$ spiperone was also used as a radioligand (MacKay et al., 1978). As an added complication, under some conditions ${ }^{3} \mathrm{H}-\mathrm{YM}$ 09151-2 and ${ }^{3} \mathrm{H}$-raclopride appear to label many more "receptors" than ${ }^{3} \mathrm{H}$-spiperone. Seeman (1993a) has offered the explanation that ${ }^{3} \mathrm{H}$-spiperone binds to dimers of dopamine receptors, which could account for the difference. Clearly, the pharmacological characteristics of these ligands need additional investigation.
This study has significant methodological limitations. The first is the complicated approach to the labeling of putative D4 receptors in that the specificity of the findings is dependent on subtracting the specific binding of two radioligands. Such an approach can lead to increased variability, but in the current absence of specific D4 radioligands, this is the only available approach. Another approach would be to perform ${ }^{3} \mathrm{H}-\mathrm{YM}$ 09151-2 binding in the presence of a cold saturating concentration of raclopride. This was attempted by Seeman (1993a) using ${ }^{3} \mathrm{H}-\mathrm{YM} 09151-2$ in the presence of $200 \mathrm{~nm}$ raclopride, and was unsuccessful because it eliminated the binding of ${ }^{3} \mathrm{H}-\mathrm{YM}$ 09151-2 to the control tissue, making comparisons with the schizophrenic tissue difficult (Seeman et al., 1993a).

Despite these reservations, there is a twofold increase in some receptor population, possibly $\mathrm{D} 4$, in the schizophrenic group relative to the control groups. In order to confirm that these 


\section{D4}

[3H]YM 09151-2 - [3H]raclopride

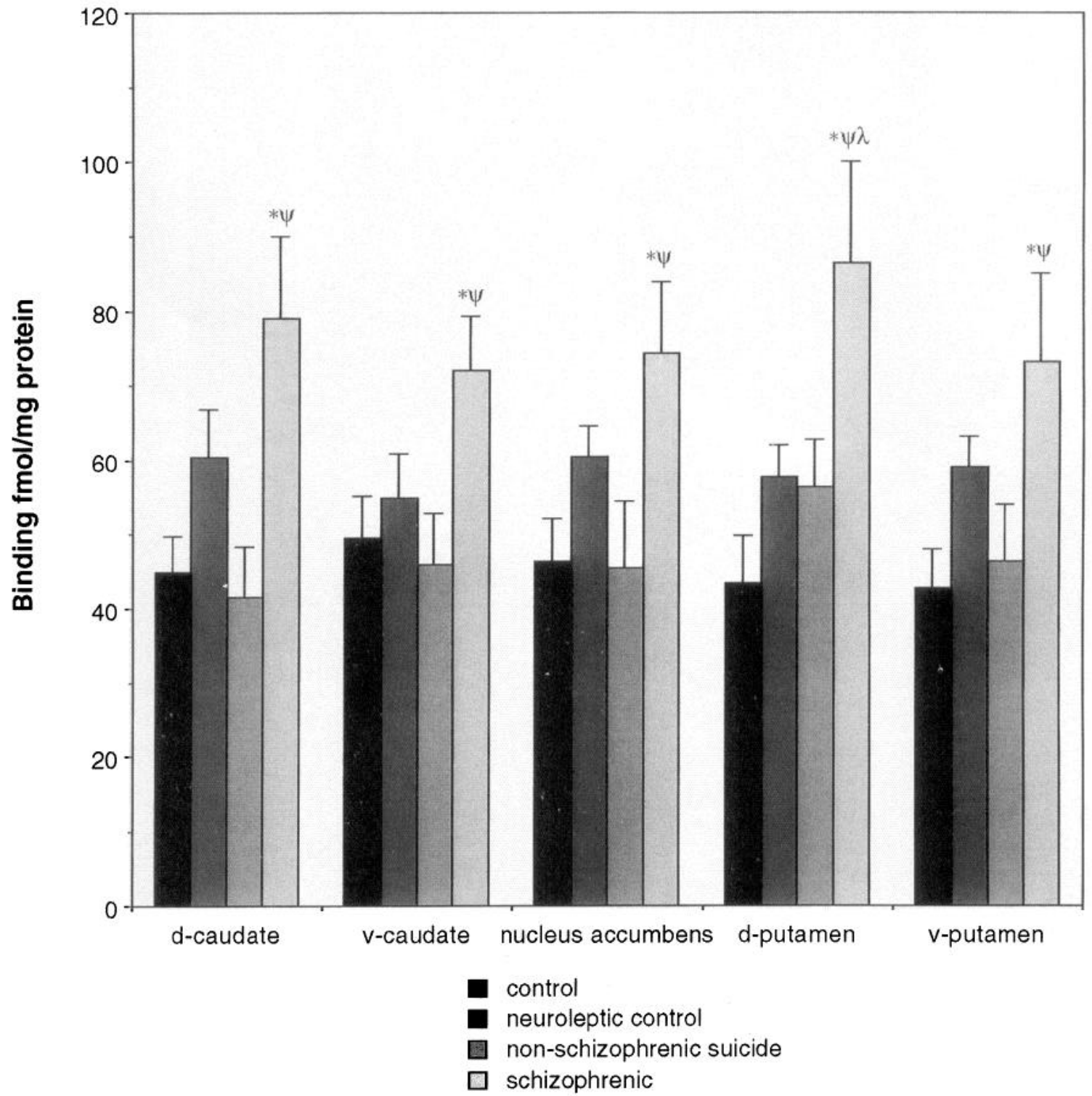

Figure 2. Graphic representation of the mean \pm SEM of D4 receptor binding in control, neuroleptic control, nonschizophrenic suicide, and schizophrenic groups. Regional binding densities are shown for dorsal caudate, ventral caudate, nucleus accumbens, dorsal putamen, and ventral putamen. ${ }^{*} p<0.05$, schizophrenic versus control, ${ }^{4} p<0.05$, schizophrenic versus nonschizophrenic suicide; ${ }^{\lambda} p<0.05$, schizophrenic versus neuroleptic control. Units are expressed in $\mathrm{fmol} / \mathrm{mg}$ protein.

changes are truly D4 receptors, it would be best to repeat such experiments using a specific D4 receptor ligand, when such a compound becomes available.

\section{References}

Alexander GE, Crutcher MD, DeLong MR (1990) Basal ganglia-thalamocortical circuits: parallel substrates for motor, oculomotor, "prefrontal" and "limbic" functions. In: Progress in brain research, Vol 85 (Uylings HBM, Van Eden CG, De Bruin JPC, Corner MA, Feenstra MGP, eds), pp 119-146. New York: Elsevier.

Connell PH (1958) Amphetamine psychosis. London: Oxford UP.

Creese I, Burt DR, Snyder SH (1976) Dopamine receptor binding predicts clinical and pharmacological potencies of antischizophrenic drugs. Science 192:481-483.

Cross AJ, Crow TJ, Owen F (1981) ${ }^{3} \mathrm{H}$-flupenthixol binding in post- mortem brains of schizophrenics: evidence for a selective increase in dopamine D2 receptors. Psychopharmacology (Berlin) 74:122-124.

Farde L, Wiesel FA, Stone-Elander S, Halldin C, Nordstrom AL, Hall H, Sedvall G (1990) D2 dopamine receptors in neuroleptic-naive schizophrenic patients. A positron emission tomography study with [" ${ }^{11}$ C]raclopride. Arch Gen Psychiatry 47:213-219.

Grandy DK, Marchionni MA, Makam H, Stofko RE, Alfano M, Frothingharn L, Fischer JB, Burke-Howie KJ, Bunzow JR, Server AC, Civelli O (1989) Cloning of the cDNA and gene for a human D2 dopamine receptor. Proc Natl Acad Sci USA 86:9762-9766.

Griffith JD, Cavanaugh J, Held J, Oates JA (1972) Dextroamphetamine: evaluation of psychomimetic properties in man. Arch Gen Psychiatry 26:97-100.

Hess EJ, Bracha HS, Kleinman JE, Creese I (1987) Dopamine receptor sub-type imbalance in schizophrenia. Life Sci 40:1487-1497.

Hietala J, Syvalahti E, Vuorio K, Nagren K, Lehikoinen P, Ruotsalainen 
U, Rakkolainen V, Lehtinen V, Wegelius U (1994) Striatal D2 dopamine receptor characteristics in neuroleptic-naive schizophrenic patients studied with positron emission tomography. Arch Gen Psychiatry 51:116-123.

Kleinman JE, Nawroz S (1994) Schizophrenia: postmortem studies. In: Biology of schizophrenia and affective disease (Watson SJ, ed). New York: Raven.

Knable MB, Hyde TM, Herman MM, Bigelow LB, Kleinman JE (1994) Quantitative autoradiography of dopamine-D1 receptors, D2 receptors and dopamine uptake sites in post-mortem striatal specimens from schizophrenic patients. Biol Psychiatry, in press.

Kornhuber J, Riedirez P, Reynolds G, Beckmann H, Jellinger K, Gabriel E (1989) ${ }^{3} \mathrm{H}$-Spiperone binding sites in post-mortem brains from schizophrenic patients: relationship to neuroleptic drug treatment, abnormal movements, and positive symptoms. J Neural Transm 75:110.

Lee T, Seeman P (1980) Elevation of brain neuroleptic/dopamine receptors in schizophrenia. Am .J Psychiatry 137:191-197.

Lee T, Seeman P, Tourtellotte WW, Farley IJ, Hornykeiwicz O (1978) Binding of ${ }^{3} \mathrm{H}$-neuroleptics and ${ }^{3} \mathrm{H}$-apomorphine in schizophrenic brains. Nature 274:897-900.

Mackay AV, Doble A, Bird ED, Spokes EG, Quik M, Iversen LL (1978) ${ }^{3} \mathrm{H}$-spiperone binding in normal and schizophrenic post-mortem human brain. Life Sci 23:527-532.

Mackay AV, Iversen LL, Rosser M, Spokes E, Bird E, Arregui A, Creese I, Snyder SH (1982) Increased brain dopamine and dopamine receptors in schizophrenia. Arch Gen Psychiatry 39:991-997.

Martinot JL, Peron-Magnan P, Huret JD, Mazoyer B, Baron JC, Boulenger JP, Loch C, Maziere B, Calliard V, Loo H, Syrota A (1990) Striatal D2 dopaminergic receptors assessed with positron emission tomography and $\left[{ }^{76} \mathrm{Br}\right]$ bromospiperone in untreated schizophrenic patients. Am J Psychiatry 145:44-50.

Meador-Woodruff JH, Grandy DK, Van Tol HHM, Damask SP, Little KY, Civelli O, Watson SJ (1994a) Dopamine receptor gene expression in the human medial temporal lobe. Neuropsychopharmacology, in press.

Meador-Woodruff JH, Mansour A, Saul J, Watson SJ (1994b) Neuroanatomical distribution of dopamine receptor messenger RNA's. In: Dopamine receptors and transporters: pharmacology, structure, and function (Niznik HB, ed), pp 403-415. New York: Dekker.

Mita T, Hanada S, Nishino N, Kuno T, Nakai H, Yamadori T, Mizoi Y, Tanaka C (1986) Decreased serotonin S2 and increased dopamine D2 receptors in chronic schizophrenics. Biol Psychiatry 21:14071414.

Mjorndal T, Winblad B (1986) Alteration of dopamine receptors in the caudate nucleus and the putamen in schizophrenic brain. Med Biol 64:351-354.

Oades RD, Halliday GM (1987) Ventral tegmental (A10) system: neurobiology. 1. Anatomy and connectivity. Brain Res Rev 12:117-165.

Owen F, Cross AJ, Crow TJ, Longden A, Poulter M, Riley GJ (1978) Increased dopamine receptor sensitivity in schizophrenia. Lancet $2: 223-226$

Seeman P (1992) Dopamine receptor sequences. Therapeutic levels of neuroleptics occupy D2 receptors, clozapine occupies D4 receptors. Neuropsychopharmacology 7:261-284.

Seeman P, Lee T, Chau-Wong M, Wong K (1976) Antipsychotic drug doses and neuroleptic/dopamine receptors. Nature 261:717-719.

Seeman P, Bzowej NH, Guan HC, Bergeron C, Reynolds GP, Bird ED, Riederer P, Jellinger K, Tourtellotte WW (1987) Human brain D1 and D2 dopamine receptors in schizophrenia, Alzheimer's, Parkinson's and Huntington's disease. Neuropsychopharmacology 1:5-15.

Seeman P, Guan H-C, Niznik HB (1989) Endogenous dopamine lowers the dopamine D2 receptor density as measured by $\left[{ }^{3} \mathrm{H}\right] \mathrm{raclopride}$ implications for positron emission tomography of the human brain. Synapse 3:96-97.

Seeman P, Guan H-C, Van Tol HHM (1993a) Dopamine D4 receptors elevated in schizophrenia. Nature 365:441-445.

Seeman P, Guan H-C, Van Tol HHM, Niznik HB (1993b) Low density of dopamine D4 receptors in Parkinson's, schizophrenia and control brain striata. Synapse 14:247-253.

Sibley D, Monsma F (1992) Molecular biology of dopamine receptors. Trends Pharmacol Sci 13:61-69.

Sokoloff P, Giros B, Martres M-P, Bouthenet M-L, Schwartz J-C (1990) Molecular cloning and characterization of a novel dopamine receptor (D3) as a target for neuroleptics. Nature 347:146-151.

Sunahara RK, Niznik HB, Weiner DM, Storrnann TM, Brann MR, Kennedy JL, Gelernter JL, Rozmahel R, Yang Y, Israel Y, Seeman P, O'Dowd BF (1990) Human dopamine DI receptor encoded by an intronless gene on chromosome 5. Nature 347:80-83.

Sunahara RK, Guan HC, O'Dowd BF, Seeman P, Laurier LG, Ng G, George SR, VanTol HHM, Niznik HB (1991) Cloning of the gene for a human dopamine D5 receptor with higher affinity for dopamine than D1. Nature 350:614-619.

Van Tol HHM, Bunzow JR, Hong-Chang G, Sunahara RK, Seeman P, Niznik HB, Civelli O (1991) Cloning of the gene for a human dopamine D4 receptor with high affinity for the antipsychotic clozapine. Nature 350:614-619.

Wong DF, Wagner HN Jr, Tune LE, Dannals RF, Pearlson GD, Links JM, Tamminga CA, Broussolle EP, Ravert HT, Wilson AA, Toung JKT, Malat J, Williams JA, O'Trauma LA, Snyder SH, Kuhar MH, Gjedde A (1986) Positron emission tomography reveals elevated D2 dopamine receptors in drug-naive schizophrenics. Science $234: 1558-$ 